Research Article

\title{
Financing of HAJ Trough a Contract of Qardh (Loan) on Shari'a Banking in Indonesia
}

\author{
Sufmi Dasco Ahmad \\ Member of Parliament, Indonesia
}

\begin{abstract}
Haj Bailout Funds is a loan facility given by shari'abank to customers, which has aims to close the shortcomings of BPIH(Hajj Operational/ Investment Funds) in order to get hajj portion (seat). This Hajj bailout funds actually causes some mudharat, including the existing people who have not able to engage hajj (istitha'ah) are able to register for hajj, thus it makes the queue list for hajj becomes longer and longer that is about 10 years. The application of Qardh on shari'abanking based on MUI Fatwa No. 19/DSN-MUI/IV/2001 whose funds is sourced from capital share and profit set aside from Lembaga Keuangan Syariah/ LKS(Shari'a Financial Institution), and also other institutions and individuals who entrust their infaqdistribution through LKS. In 2011, MUI released a fatwa Qardh in No. 79/DSN-MUI/III/2011 whose funds source is from the customers. If it is compared to MUI fatwa 2001, this MUI fatwa 2011 possible can take more mudharatif there are some uncollectible qardh accounts receivables because its fund source is from the customers. The other mudhorotis when someone is not able to pay off the DHT, thus it creates a cancellation of hajj departure.
\end{abstract}

Key words: Haj Bailout, Financing, Shari’a Banking

\section{A. Introduction}

Hajj is the fifth pillar of Islam. For some people who are capable of carrying out Hajj, it is required for them to fulfill it. However, as the developing of economy and the soaring of the number of hajj pilgrims, it makes the cost of hajj pilgrimage becomes more increasing every year. Besides that, the more day pass, the number of hajj pilgrims who are in line to register for hajj also increases. Hajj for Moslems is a main obligation of the pillars of Islam. Hajj is incumbent to be carried out once in lifetime for every Muslim who has belonged to mukallaf category, which means mature and has sense, and has capability to perform it.

The strong desire of society in order to fulfill hajj pilgrimage currently is supported and facilitated by the existing facilitates given by the Shari'a Banking which gives hajj bailout funds through some shari'a financing products, one of them is Qardh social product. The wisdom of the ordered Qardh for example is performing Allah's will that Muslims should help each other in goodness and piety. Other wisdom is strengthening ukhuwah (fraternity) by giving some help to other people who need it and are having difficulties and in hurry in lightening up their burden of suffering. Hajj Bailout Funds is a loan facility which is given by sharia bank to customers, which aims to cover the lack BPIH (Hajj Operational/ Investment Funds) in order to get hajj portion.

In Indonesia, the implementation of Qardh on sharia banking is based on MUI fatwa Number 19/DSN-MUI/IV/2001, whose funds is from capital share and profit which is set aside from the Lembaga Keuangan Syariah (LKS), and other institutions or individuals who entrust their infaq distribution through LKS. On 2011, MUI reissued Qardh fatwa Number 79/DSNMUI/III/2011 whose source of funds was from the customers.
In accordance with MUI Fatwa Number 19/DSNMUI/IV/2001 on al-Qaordh, it is stated that the source of Qardhfunds can come from: (a) Capital Share of Lembaga Keuangan Syariah (LKS); (b) The Profit of Lembaga Keuangan Syariah (LKS) which is set aside; (c) Other institutions or individuals who entrust their infaq distribution through Lembaga Keuangan Syariah (LKS).

In 2011, MUI reissued fatwa Number 79/DSN-MUI/III/2011 on al-Qardh by using Customers' Funds. In this fatwa, in is explained in detailed some transactions which are permitted to be financed by customers' funds, that is Contract of Qardh which is carried out as a means or completeness requirements for other transactions that use mu'awadhaakad (exchange and can be commercial in nature) in some products which aim to get any profit, whereas some transactions which are not financed by customers' funds are Contract of Qardhwhich are standing alone with a purpose for merely social purpose as intended in Fatwa Number 19/DSN-MUI/IV/2001 on alQardh, not as a means or completeness requirement for other transactions in the products which has an aim to get any profit.

In the content of this contract, it is clearly stated that customers who are intending to borrow the Hajj Bailout Funds have to be willing to propose an application to the Bank in order to perform the arrangement of Hajj Pilgrimage Funds. It indicates that the bank are opening up an opportunity for owing some loans for some customers who probably have not had capability to pay the Haj Pilgrimage Funds, however with a persuasion of getting some loans from sharia banking, the customers have to hand over the hajj registration to the bank. It means that the sharia bank is willing to give the Hajj Bailout Funds because there is some profit which will be received 


\section{Sufmi Dasco Ahmad / Financing of HAJ Trough a Contract of Qardh (Loan) on Shari'a Banking in Indonesia}

from the transaction that is some earnings in the form of administrative costs and ujrah.

Contract of Qardhis allowed with two requirements: (1) It does not make any profit. If the profit is for the lender, thus the ulamas agree that it is not allowed, because there is a prohibition from the shari'a and because it has come out from path of virtue; (2) Thiscontract of Qardhis not accompanied by other transactions, such as sale, etc.

Hajj Bailout Funds actually will cause some mudhorat, including the presence of society who actually have not been able to perform hajj (istitha'ah) can register for hajj, thus it makes the queue list for hajj becomes longer, that is about 10 years. Other mudharatis when someone is not able to cover the DHT that creates hajj departure cancelation and finally creates a chaos in the SISKOHAT. On the other hand, the facility of Hajj Bailout Funds is able to increase the society's interest to perform Hajj and is one of the manifest of Maslahah Theory, that is an activity which has aim to increase society's awareness on ad-Dien, that is human's activity which is embodied in the implementation of the fifth pillar of Islam.

\section{B. Methodology}

The study in this article belongs to normative legal research or doctrinal, whereas from its form, it belongs to descriptive analytical study. Analysis used in this study is qualitative analysis. Type of data used in this study is Secondary Data, which consists of: primary, secondary, and tertiary legal entities, where as the source of data is legislations, literature study, documentary materials, scientific writings, and other written sources.

\section{Literature Review}

Hajj according to shari'a understanding means going to Baitullah (Kaaba) to perform certain deeds, or hajj means making pilgrimage to certain places on a certain time in order to perform certain deeds (Az-Zuhaili, Wahbah, 2011”368, $385)$.

Hajj for Muslims is a prime obligation from the Pillars of Islam. Hajj is compulsory to be done once in a lifetime by every muslim who has belonged to mukallaf category, which means mature and has sense, and has a capability to perform it.

This capability requirement is related to the specific nature of hajj itself, that is only can be done on a certain time and place, that is in the Arabian Saudi, city of Mecca. This capability includes travel costs and life cost, healthy physically and psychologically, security and safety guarantee at the pilgrimage and adequacy of living for the family they leave. All muslims who have this capability is required to immediately carry out it (Balai Penelitian dan Pengembangan Agama Semarang, 2015: 2)

Sharia Banking which gives hajj bailout funds through sharia financing products, one of them is through social product of Qardh. In accordance to MUIFatwa Number 19/DSN-
MUI/IV/2001 on al-Qardh, states that the sources of Qardh funds are from: (a) Capital Share of Lembaga Keuangan Syariah (LKS); (b) the Profit of Lembaga Keuangan Syariah (LKS) which is set aside; (c) Other institutions or individuals who entrust their infaqdistribution through Lembaga Keuangan Syariah (LKS).

\section{Discussion}

Regulation Number 21 of 2008 which regulates exclusively the shari'a banking states that the shari'a compliance issues whose authority is under MajelisUlama Indonesia has to follow up the implementation of some fatwas issued by MUI on its implementation of business activities. Business activities which are grounded on Shari'a principles are regulated in Article 2 Regulation Number 21 2008, which prohibits any business activities that contain: (1) Riba, that is additional revenue unrightfully (batik) for examples in the exchange of some goods which do not has the same quality, quantity, and the time of submission $(f a d h l)$ transactions, or in lending and borrowing transaction which has a certain requirement where the Customers of Facility Receiver has to return some funds he receives more than the loan because of the time spend to return it (nasi'ah); (2)Maisir is a transaction which is hanged on a certain condition which is uncertain and chancy; (3) Grahar is a transaction whose object is not clear, not owned, and unknown its existence or can not be submitted at the time the transaction is performed, except it is regulated separately in the sharia; (4) Haram is a transaction whose object is prohibited in the sharia; and (5) Zalim is a transaction which causes injustice for other parties (the Explanation of UU Number 21/2008). In the General Explanation of Act $9 \mathrm{~g}$ Regulation Number 21 of 2008 on Sharia Banking, it is stated that something which is meant by contract of qardh is loan contract of some funds to a customer with a provision that the customer has to return the funds he has received at the time they have agreed. Financing business activity based on contract ofQardhis regulated on the provision of Act 19 e, Regulation Number 2008 as follows: distributing the financing based on contract of qardh or other contracts which do not contradict to the sharia principles.

Qardh is similar to loan, the same with something written in Contract of Qardh for Advance Payroll, Hajj Bailout Funds, and contract ofQardh, Rahn, andIjarah. It is corresponding to the essence of qardh itself which has meaning lending some properties. This contract of Qardh is one of contract oftabarru' which is fi' $i l$ form of word Birr. Birr is from the word barra-yabarru-barranwabirran. Al-birr is mentioned in the context of reproach to some people who doing birr, but they forget that they (do not do something which is ordered).

The Fatwa of National Sharia Board Number 19/DSNMUI/IV/2001 on Al-Qardhactually does not give explicit explanation on the objects of Qardh which can be implemented by the sharia banking, thus each sharia bank has its own implementation policy.

The administration of Regular Haj Bailout Funds facility which is given by sharia bank to the customers has an aim to 


\section{Sufmi Dasco Ahmad / Financing of HAJ Trough a Contract of Qardh (Loan) on Shari'a Banking in Indonesia}

cover the deficiency of BPIH (Hajj Operational/Investment Costs) in order to get the hajj portion. In order that the Hajj Bailout Funds is in accordance to the agreed contract of Qardh, the customer is required to return a certain amount of money on a certain period of time. After contract Qardhis performed, the sharia bank will do some arrangement of the needed files in order to get the number of hajj portion from the SISKOHAT (Integrated Computerization System of Hajj). From the service of files arrangement, the sharia bank will get some rewards in the form of administrative costs which should be payable by the customer in a predetermined amount at the beginning of the contract and it is not related to the amount of loan given by the sharia bank.

All this time, there has not been any customer who receives Hajj Bailout Funds without any intervention of sharia bank in the arrangement of files in getting hajj portion from the SISKOHAT. It means that sharia bank will only give the Hajj Bailout Funds if the customer is willing to submit the arrangement of his files to the sharia bank until he gets the number of hajj portion from the SISKOHAT, thus if it is related to the Fatwa of DSNMUI Number 29/DSNMUI/VI/2002, the arrangement of files which is done by sharia bank in order to get hajj portion contradicts to the general provision of this fatwa of DSN, especially provision Number 3. Therefore, it can be said that the execution of administration of Hajj Bailout Funds facility which is given by sharia bank is contravene to Fatwa DSN (National Sharia Council) MUI Number 29/DSN-MUI/VI/2002.

Most of the sources of Hajj Bailout Funds are from the Third Party Funds, especially from Wadiahyad-dhamanah current account, Wadiahyad-Dhamanahcurrent account is a deposit with a principle that the deposited party (bank) is responsible for the wholeness of this deposits, thus it is allowed to utilize those deposits (Karim, 2007: 108). Wadiahyad-Dhamanah current account only can get such a rewards based on the Bank policy. Here, the sharia bank has a full discretion to manage the customers' money without thinking about the number of rewards/bonus that should be given to the customers, whereas the customers do not have any discretion to get more leverage bonus.

Thereare two models of Hawalah which are practiced on sharia banking: hawalahbilujroh and hawalahbilmurahabah, hawalahbilmudharobahorhawalahbilmusyarakah.

The implementation of hawalahbilujrah on sharia banking if it is referenced to the Fatwa of National Sharia Council MUI Number 58/DSN-MUI/V/2007 on Hawalahbilujroh actually has been appropriate, but ujrah that should customer pays with a calculation equals to the Murabahahmargin needs to be reviewed. It is because contract of hawalahis a contract of tabarru' which has aim to help other people in troubles, so that if the amount of hujrahwhichis paid is more than the actual costs, the initial purpose of giving the help becomes void. Moreover, in contract of tabarru', it is not permitted that there are some additional benefits obtained by the bank, because it means that it is mixing contract of tabarru' and contract of tijarah.
Next, the second form of hawalah is hawalahbilMurabahah, hawalahbilMudharabah, and HawalahbilMusyarakah with ujrahwhich is adjusted to the amount of margin for contract of Murabahahand the amount of profit sharing for contract of Mudharanahand contract of Musyarakah. It means that ujrah which is obtained from those contract is forbidden to be recognized, because according to sharia, making multicontracts of tabarru' and tijarahis prohibited.

MazhabHanafi on his strong notion (rajah), states that qardh which produces some profit is forbidden in Islamic law, if this profit is conditioned previously. If the profit is not conditioned previously and is not a habitual tradition, it is permitted. Therefore, the receiver of pledge goods (at this context the lender) is not permitted to make use of his pledge if it is conditioned previously or it is a habitual customs. If not so, it is allowed, but the law is makruhtahrim except there is permission from thelender, so it is not makruh anymore as included in mu'tabar books of Hanafiyah. But, some ulamas still state it is not allowed, although there has been permission from the lender. It is this opinion which is in accordance to the sharia soul related to the prohibition of usury. Likewise, rewards for the lender, if there has been determined previously in the requirement, so the law is makruh (it means prohibited), if it is not predetermined it is not makruh.

Malikiyahulamas contend that contract of qardhwill illegitimate if it gives some profit, because it can be included as usury. It is prohibited to take some benefits from the borrower's property. Likewise, some gift from the borrower is also prohibited for the property's owner the purpose is to delay the debt payments where there is not any customs of giving some gift to people who lends some money, and there is not any new reason for example because they are family in law or neighbors, in which the present is intended to strengthen these relationship not because of debts reason. This law is applied for the receiver and also giver of the present, so it is required that they has to return back the property, for example if the present is in the form of mitsli and an equivalent value if the goods is qimiy.

All those provision is applicable if there is still a debts bond between the lender and the borrower. Whereas at the time of debt repayment, if the borrower gives extra payment and his debts is caused by sale activity, it is absolutely permitted either the goods is better on its nature or its size, either it is paid at the time determined, before or after. If the debt is caused by contract ofqardh, if the extra payment is a requirement, promise or a habitual customs, it is absolutely prohibited. If it is not a requirement, promise or a habitual customs, it is allowed according to Malikiyah agreement. It is applicable to some goods with better quality, because Prophet Muhammad SAW when he borrows a young camel he will pay it with older and selected camel. But, if this extra is better in size, in al-Mudawwanahbook which contains the opinion of Imam Malik, it is explained that extra payment is not allowed, except in small quantities. It is different to IbnuHabib who absolutely allows it. 
Syafiiyah and Hanabilahulamas have opinion that qardh which gives some profit is not allowed, for example lending 1000 dinar with a requirement that the borrower should sell his house to the lender, or with a requirement that the borrower should return 1000 dinar with better quality of dinar coin or return more that the main loan. The reason is that the Prophet Muhammad SAW prohibits contract of salaf (debts) together with sale.Salafis qardhin Hijaz society's language. Besides that, there is a history from Ubay bin $\mathrm{Ka}$ 'ab, IbnuMas'ud, and Ibnu Abbas ra that they prohibit a qardh that withdraws some profit. Likewise, qardh is a mutual help qardh and is worship. Therefore, at this situation, contract of qardhis still legitimate but with a requirement that the profit is canceled, either in the form of money or goods, much or little.

If a person is lending some money or goods without any certain requirements, then the borrower pays it with some goods with better quality or value, or he sells his house to the lender, it is allowed and the lender is allowed to take it. It is based on story of Abu Rafi' ra, he states that, "Muhammad Rasulullah has ever owed a $b a k r$ camel to a person, than he get a charity camel. Thus, he asks me to pay to the person a $b a k r$ camel. Whereas, some prohibition of qardh which produces some profit, accordingly it is not a hadith, as it is confirmed by Hafidhaz-Zaila'i on his book NasburRaayah, and explained on his Hasyiah. But, it can also be understood that the prohibition is only related to the qardh which accompanied by profit requirements or qardh that gives some profit in accordance to habitual customs as it is explained by al-Kharki and other ulamas.

In summary, akadqardh is allowed with two requisites: it does not gives any profit and this akadqardh is not accompanied by other transactions, for example buy and sell, etc.

\section{E. Conclusion}

Operational basis for Qardh in Sharia Banking for hajj bailout funds financing in Indonesia are regulated as follows: the Regulation of Ministry of Religious Affairs of Republic of Indonesia No. 30 of 2013, regarding the Recipient Bank of Hajj Pilgrimage Management Cost and Fatwa MUI for the Hajj Bailout Funds is Fatwa of DSN (National Sharia Council)MUI No. 29/DSN-MUI/VI/2002, date $26^{\text {th }}$ of June 2002, regarding the Cost of Hajj Arrangement by LKS (Lembaga Keuangan Syariah).Qardh uses contract of ijarah. Qardh which gives some profit is forbidden if the profit is required previously. If it is not required previously and it is not a habitual custom, then the law is mubah. In order to make better management, it is better that Hajj Bailout Funds is replaced by Hajj Savings, thus the concept of hajj is not in the form of loan but capability. 